\title{
EOGARTHAMBRUS GUINOTAE N. GEN. AND N. SP. (DECAPODA, BRACHYURA, PARTHENOPIDAE) FROM THE EOCENE OF VICENZA, ITALY
}

\author{
BY \\ ANTONIO DE ANGELI ${ }^{1,4}$ ), ALESSANDRO GARASSINO ${ }^{2,5}$ ) \\ and RICCARDO ALBERTI ${ }^{3,6}$ ) \\ 1) Piazzetta Nostro Tetto, 9, I-36100 Vicenza, Italy; Museo Civico G. Zannato, \\ Piazza Marconi, 15, 36075 Montecchio Maggiore (Vicenza), Italy \\ 2 ) Museo Civico di Storia Naturale di Milano, Corso Venezia, 55, I-20121 Milano, Italy \\ 3 ) Associazione Amici del Museo Civico G. Zannato, Piazza Marconi, 15, \\ I-36075 Montecchio Maggiore (Vicenza), Italy
}

\begin{abstract}
Eogarthambrus guinotae n. gen., n. sp. (Parthenopidae MacLeay, 1838) is described from the Eocene (Ypresian and Priabonian) of Vicenza, northern Italy.

The shape of the carapace shows affinities with the extant representatives of Garthambrus $\mathrm{Ng}, 1996$, but differs in the shape of the front and the hepatic margin. Even if strong affinities also exist with the fossil Mesolambrus Müller \& Collins, 1991, from the late Eocene (Priabonian) of Hungary, the new genus differs in having a narrower front with two median teeth, anterolateral margins that form an acute angle and have five wide, flat spiny teeth.

Eogarthambrus n. gen. and Mesolambrus were widespread in the Eocene seas of Europe, having preference for coral reef environments.
\end{abstract}

\section{RÉSUMÉ}

Eogarthambrus guinotae n. gen., n. sp. (Parthenopidae MacLeay, 1838) est décrit de l'Éocène (Yprésien et Priabonien) de Vicenza, Italie du nord. La forme de la carapace montre des affinités avec les espèces éteintes de Garthambrus $\mathrm{Ng}$, 1996, mais en diffère par la forme du front et du bord hépatique. De fortes affinités existent également avec les fossiles de Mesolambrus Müller \& Collins, 1991 de l'Éocène supérieur (Priabonien) de Hongrie. Le nouveau genre en diffère par un front plus étroit avec deux dents médianes, bord antérolatéral

\footnotetext{
$\left.{ }^{4}\right)$ Corresponding author; e-mail: antonio.deangeli@alice.it

5 ) e-mail: agarassino63@gmail.com

6) e-mail: riccardoalberti@ libero.it 
formant un angle aigu et avec cinq dents aplaties, larges et pointues. Eogarthambrus n. gen. et Mesolambrus étaient largement répartis dans les mers d'Europe à l'Éocène, de préférence dans les environnements corallines.

\section{INTRODUCTION}

The present specimens come from the early Eocene (Ypresian) of the Rossi quarry of Monte di Malo and from the late Eocene (Priabonian) of San Feliciano, Orgiano (Vicenza, northern Italy).

The quarry, located on the eastern side of Monti Lessini Vicentini, represents one of many quarries where nummulitic limestones are extracted. Many decapod crustaceans have been discovered and described by Beschin et al. (1988, 1996, 1998, 2000, 2007b).

The micropalaeontologic study of the quarry was carried by Beschin et al. (1998), Beccaro (2003) and Beccaro et al. (2001). These authors recognized three different levels containing decapod crustaceans. The first two levels, located in the lower part of the quarry, are middle Ypresian (Nummulites nitidus zone) and late Ypresian (Nummulites campesinus zone), both composed of an alternation of grey-green volcanodetritic materials, micritic limestone, and calcarenite; the third level, at the top of the quarry, and middle Lutetian in age, is composed of micrite and tufaceous micrite (Morozovella lehneri zone).

The quarry is also known to have yielded small fragments of Eocene amber (Boscardin \& Violati Tescari, 1996; Ragazzi, 1998; Trevisani et al., 2005).

One of the present specimens was discovered in the layers located below the levels containing previously known decapods (Beschin et al., 1998). These layers, perhaps from patch reefs, are composed of stratified calcarenites, are rich of coralligenous algae and corals, associated with natural moulds of molluscs, decapod crustaceans, and macroforaminifers. One similar formation was identified from the middle Ypresian of Contrada Gecchelina of Monte di Malo (Vicenza, Italy), where 350 fossil decapods belonging to 48 species were collected (Beschin et al., 2007a).

The second specimen, from the quarry of San Feliciano Hill, Orgiano (south-western Monti Berici, Vicenza), was discovered in calcarenites rich in corals of late Eocene (Priabonian) age. The holotype of Phlyctenodes dalpiazi studied and described by Fabiani (1911), and housed in the collections of the University of Padova, comes from this level. The discovery of many decapods from this calcarenitic level has resulted in the description of many galatheid, 


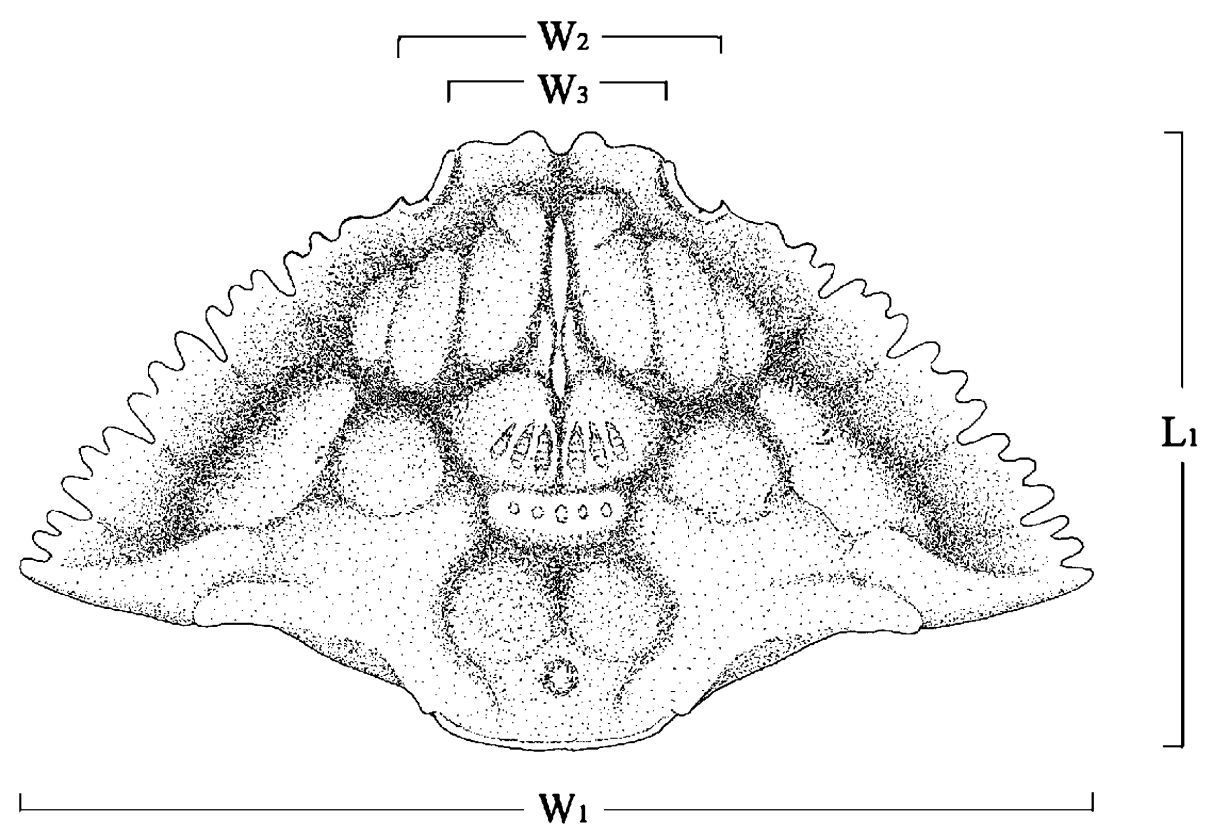

Fig. 1. Eogarthambrus guinotae $\mathrm{n}$. gen., n. sp., carapace reconstruction; $\mathrm{W}_{1}=$ maximum width of the carapace; $\mathrm{W}_{2}=$ orbito-frontal width; $\mathrm{W}_{3}=$ frontal width; $\mathrm{L}_{1}=$ maximum length of the carapace.

chirostylid, and porcellanid decapods (De Angeli \& Garassino, 2002) and one sphaeromatid isopod (De Angeli \& Lovato, 2009).

The specimens have been deposited in the palaeontological collection of Museo Civico G. Zannato of Montecchio Maggiore (Vicenza, Italy) (MCZ); the measurements (fig. 1) of the carapace are given in millimetres (mm); abbreviations: $\mathrm{W}_{1}=$ maximum width of the carapace, $\mathrm{W}_{2}=$ orbito-frontal width, $\mathrm{W}_{3}=$ frontal width, $\mathrm{L}_{1}=$ maximum length of the carapace.

\section{SYSTEMATIC PALAEONTOLOGY}

Infraorder BRACHYURA Linnaeus, 1758

Section EUBRACHYURA de Saint Laurent, 1980

Subsection HETEROTREMATA Guinot, 1977

Superfamily PARTHENOPOIDEA MacLeay, 1838

Family PARTHENOPIDAE MacLeay, 1838 


\section{Subfamily PARTHENOPINAE MacLeay, 1838}

Eogarthambrus n. gen.

Type species. - Eogarthambrus guinotae n. sp.

Diagnosis. - Carapace wider than long, steeply downturned anteriorly; front sinuous with two median lobes; orbits small, rounded, oriented obliquely; supraorbital margin well marked, raised; anterolateral margin with 5 broad, flat teeth, each with 3 spines; anterolateral tooth acute; posterolateral margins strongly convergent with 2 tubercles; regions well marked with distinct epibranchial lobes; dorsal surface finely granular.

Etymology. - Eogarthambrus (m.) is a compound name derived from Eocene, the geological age of the studied specimens, and Garthambrus $\mathrm{Ng}$, 1996, to refer to its morphological affinities with the new genus.

Remarks. - The available specimens consist of well preserved carapaces and show the typical subtriangular shape of parthenopid crabs. The morphological characters of Parthenopidae have been recently reviewed by Tan \& $\mathrm{Ng}$ (2007a, b). The genus Garthambrus has recently been revised by McLay \& Tan (2009) and some species transferred to two new genera, Zarenkolambrus McLay \& Tan, 2009 and Hispidolambrus McLay \& Tan, 2009. As a result, Garthambrus now contains 11 species from the Indo-West Pacific. Those authors also redefined some morphological terms used to describe these parthenopid species, and we follow their terminology herein.

Eogarthambrus n. gen. shows evident affinities with the Recent Garthambrus $\mathrm{Ng}, 1996$, in particular with G. complanatus (Rathbun, 1906) having a carapace with an acute, toothed dorsal angle and anterolateral margins with many flat, spiny teeth (Ng \& Tan, 1999). Garthambrus, however, has a narrower front extending beyond the orbits, a median protuberance, well marked hepatic margins, and weaker defined and less convex dorsal regions.

The shape of the carapace also shows affinities with the fossil Mesolambrus Müller \& Collins, 1991, known only by the type species M. declinatus Müller \& Collins, 1991 (cf. their pl. 3 figs. 11, 12; text-fig. 3f), from the late Eocene of Hungary.

Comparison of the new specimens with a cast of the holotype of $M$. declinatus allowed the following observations: M. declinatus differs from Eogarthambrus guinotae n. gen., n. sp. in having a carapace shorter than wide; its maximum length is found on $3 / 5$ of the width of the carapace, while in $E$. guinotae the maximum width is found on $4 / 5$ of the length of the carapace; the lateral angle teeth are convex and do not form an acute angle as in the new 
species, anterolateral and posterolateral margins have spines or lobes in the Hungarian species (E. guinotae $\mathrm{n}$. sp. has the anterolateral margins with flat teeth, each with three flat spines, and the posterolateral margins lack spines, but bear only two small tubercles), and the dorsal surface of the carapace has more tubercles than in the new species.

The specimen ascribed to Mesolambrus declinatus reported by Beschin et al. (2007a) from the early Eocene (Ypresian) of Contrada Gecchelina of Monte di Malo (Vicenza) shows the shape of its carapace to be similar to that of $E$. guinotae $\mathrm{n}$. sp. The front, however, is wider, the frontal margin is more sinuous and entirely lobate, the anterolateral margins form a convex angle with many teeth, and the dorsal surface of the carapace has more tubercles.

Eogarthambrus n. gen. and Mesolambrus represent extinct parthenopids with very large carapaces for the family, lobate fronts slightly extended beyond the orbits, protogastric regions and epibranchial lobes strongly raised and strongly inclined downward anteriorly.

\section{Eogarthambrus guinotae n. sp. (figs. 1-3)}

Material examined. - Holotype, MCZ 2992, from the early Eocene (middle Ypresian) of the Rossi quarry of Monte di Malo (Vicenza); measurements: $\mathrm{W}_{1}=44.2 ; \mathrm{W}_{2}=15.7 ; \mathrm{W}_{3}=9.6$; $\mathrm{L}_{1}=$ 26.9. Paratype, MCZ 2993, from the late Eocene (Priabonian), San Feliciano, Orgiano (Monti Berici, Vicenza), an incomplete carapace; measurements: $\mathrm{L}_{1}=11.2$.

Etymology. - The specific name honours Danièle Guinot, Département Milieux et Peuplements aquatiques, Muséum national d'Histoire naturelle, Paris, for her important contribution to the study of Recent and fossil brachyurans.

Diagnosis. - As for the new genus.

Description. - Carapace subhexagonal, wider than long $\left(\mathrm{W}_{1} / \mathrm{L}_{1}=1.63\right)$, with maximum width at $4 / 5$ of its length; dorsal surface longitudinally convex, steeply downturned anteriorly; orbito-frontal margin moderately wide $\left(\mathrm{W}_{2} / \mathrm{W}_{1}=0.35\right)$; front narrow $\left(\mathrm{W}_{3} / \mathrm{W}_{1}=0.22\right)$, slightly extended beyond orbits; frontal margin slightly sinuous; median part with 2 lobes directed downward, well marked by median incision; orbits small, rounded, oriented obliquely; supraorbital margin well marked, raised, with short, narrow supraorbital fissure; anterolateral margins elongate, convex, diverging, connecting to posterolateral margins by acute angle; anterolateral margins with 5 flat teeth, separated by narrow, deep fissures; each anterolateral tooth with 3 flat spines on outer margin; the first tooth is found on the hepatic margin and the other four teeth on the epibranchial margin; posterolateral margins shorter 

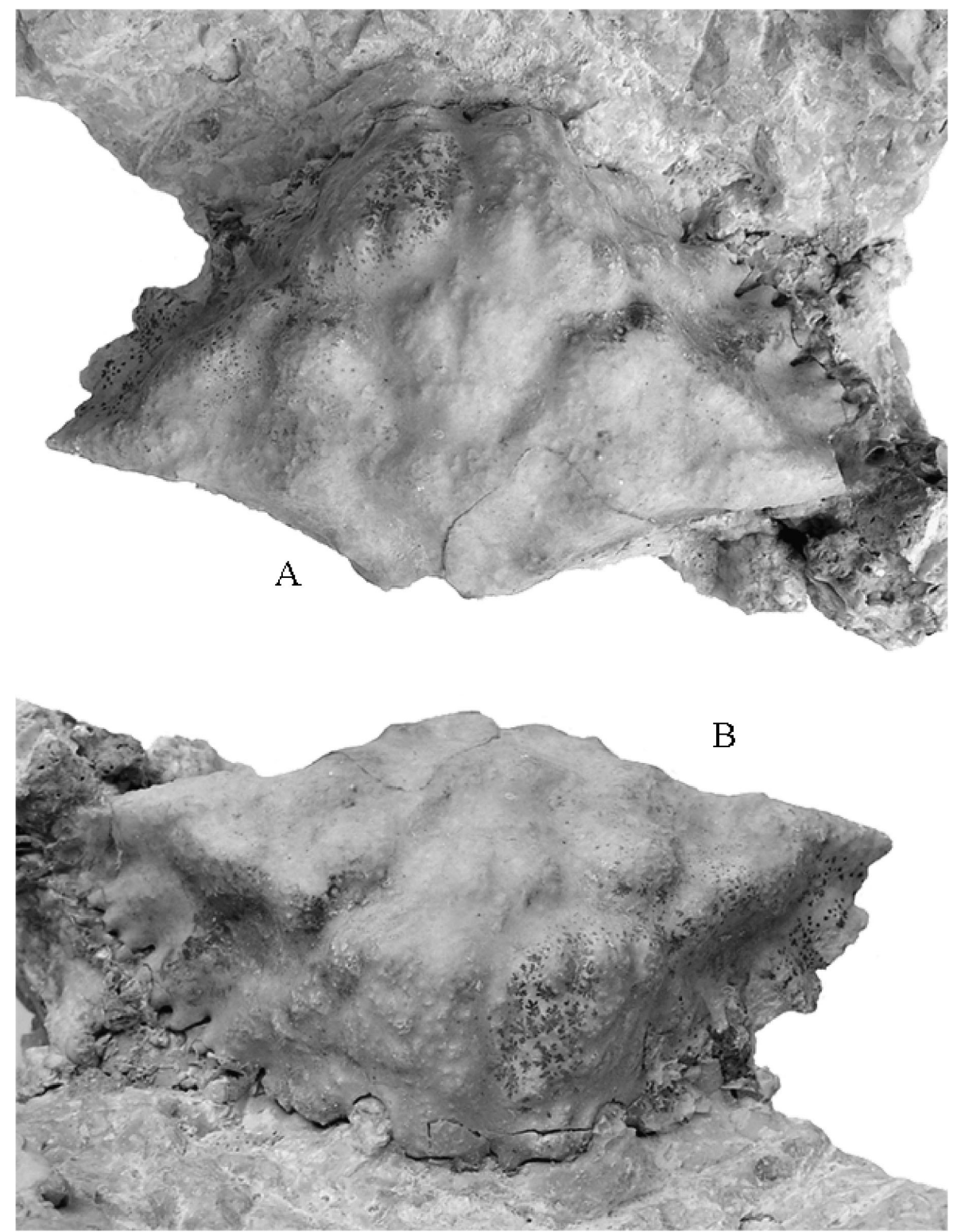

Fig. 2. Eogarthambrus guinotae n. gen., n. sp., holotype MCZ 2992; A, dorsal view; B, frontal view $(\times 2.2)$.

than anterolateral margin, strongly convergent, slightly concave; 2 small spiny protuberances, one epibranchial and one metabranchial located before posterior angle; posterior margin narrow, slightly curved; regions of carapace well marked; frontal region marked by median longitudinal depression; epigastric 

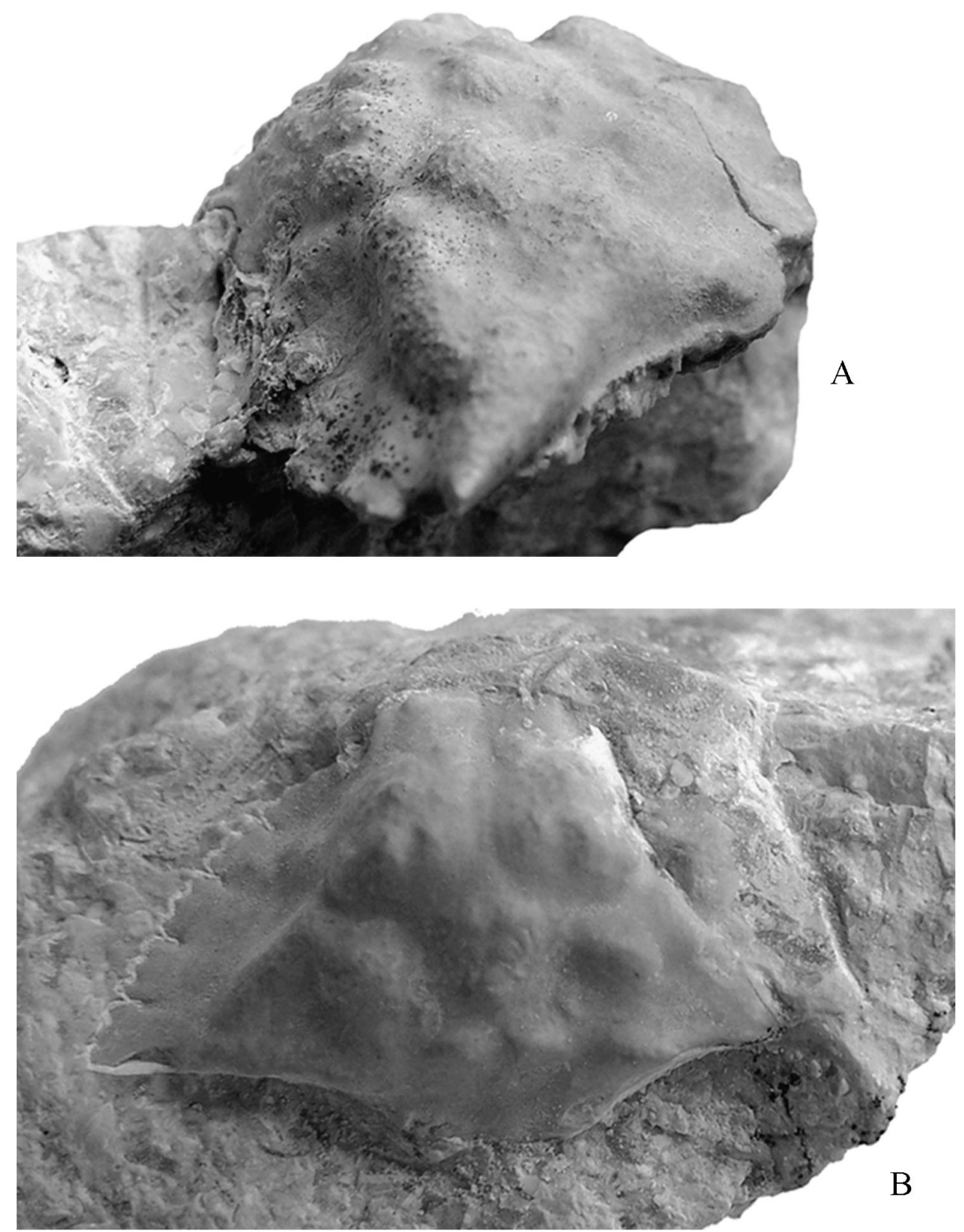

Fig. 3. Eogarthambrus guinotae n. gen., n. sp.; A, holotype MCZ 2992, oblique lateral view (×2.6); B, paratype MCZ 2293, dorsal view $(\times 4.6)$.

lobes represented by 2 small, rounded nodes; protogastric regions strongly raised, trilobate; mesogastric region well marked by cervical groove; mesogastric region subpentagonal with 2 wide elevations separated by median groove; anterior part of mesogastric region with elongated, narrow process, wedged 
between protogastric regions; metagastric region well marked with transverse, tuberculated elevation; cardiac region inflated, well marked by branchiocardiac grooves; cardiac region wider anteriorly with 2 wide circular elevations, restricted posteriorly to small node; intestinal region small, depressed; hepatic regions relatively well developed, inclined, marked by cervical groove; epibranchial regions wide with elongated, oblique elevation, extending to last tooth of anterolateral margin; additional rounded elevation present between oblique relief and gastric regions; mesobranchial regions with one weak protuberance; metabranchial regions small, with spiny tubercle; dorsal ornamentation with small irregular granulations located primarily on swellings of regions.

Remarks. - The Parthenopidae include sixteen genera represented in the fossil record: Acantholambrus Blow \& Manning, 1996 (fossil); Branchiolambrus Rathbun, 1808 (fossil); Daldorfia Rathbun, 1904 (fossil and extant); Derilambrus Tan \& Ng, 2007 (fossil and extant); Enoplolambrus A. MilneEdwards, 1878 (fossil and extant); Eogarthambrus n. gen. (fossil); Latolambrus Tan \& Ng, 2007 (fossil and extant); Heterocrypta Stimpson, 1871 (fossil and extant); Leiolambrus A. Milne-Edwards, 1879 (fossil and extant); Mesolambrus Müller \& Collins (fossil); Mesorhoea Stimpson, 1871 (fossil and extant); Parthenope Weber, 1795 (fossil and extant); Phrynolambrus Bittner, 1893 (fossil); Platylambrus Stimpson, 1871 (fossil and extant); Rhinolambrus A. Milne-Edwards, 1879 (fossil and extant); Tutankhamen Rathbun, 1925 (fossil and extant). Glaessner (1969) has considered Phrynolambrus a synonym of Pseudolambrus. In the recent study of new Italian fossil decapods, De Angeli $\&$ Beschin (2008) have seen the characteristics of Phrynolambrus and considered it a valid genus.

Eogarthambrus n. gen. and Mesolambrus, its closest similar genus, have wide carapaces with dorsal surfaces steeply downturned anteriorly, fronts slightly extended beyond the orbits, and hepatic regions margins weakly marked. Both genera originated in the Eocene Tethyan Sea, spreading into environments rich of coralligenous algae and corals, and living associated with other crustaceans (Müller \& Collins, 1991; De Angeli \& Garassino, 2002; Beschin et al., 2007a).

\section{ACKNOWLEDGEMENTS}

We wish to thank R. M. Feldmann, Kent State University, Ohio, for his careful review of and criticism on the manuscript. 


\section{REFERENCES}

BecCARo, L., 2003. Revisioni stratigrafiche nel Paleogene del Veneto occidentale. (Dottorato di Ricerca in Scienze della Terra Ciclo XVI ${ }^{\circ}$, Università degli studi di Padova, Dipartimento di Geologia, Paleontologia e Geofisica). [Unpublished Ph.D. Thesis.]

Beccaro, L., E. Fornaciari, P. Mietto \& N. Preto, 2001. Analisi delle facies e ricostruzione ambientale dei "Calcari nummulitici" (Eocene; Monti Lessini orientali — Vicenza): dati preliminari. Studi Trentini di Scienze Naturali, (Acta Geologica) 76: 3-16.

Beschin, C., A. Busulini, A. De Angeli \& G. Tessier, 1988. Raninidae del Terziario berico-lessineo (Italia settentrionale). Lavori - Società Veneziana di Scienze Naturali, 13: $155-215$.

— —, — - - — \& — - 1996. Retroplumoidea (Crustacea, Brachyura) nel Terziario del Vicentino (Italia settentrionale). Lavori - Società Veneziana di Scienze Naturali, 21: 83-102.

— —, — — — — \& — , 2007 (cf. a). I decapodi dell'Eocene inferiore di Contrada Gecchelina (Vicenza, Italia settentrionale) (Anomura e Brachyura). Museo di Archeologia e Scienze Naturali "G. Zannato", 2007: 1-76.

Beschin, C., A. Busulini, A. De Angeli, G. Tessier \& S. Ungaro, 1998. Crostacei eocenici di "Cava Rossi“" presso Monte di Malo (Vicenza - Italia settentrionale). Studi Trentini di Scienze Naturali, (Acta Geologica) 73: 7-34.

Beschin, C., A. De Angeli \& R. Alberti, 2000. Zanthopsis bruckmanni (Meyer) (Crustacea, Decapoda) dell'Eocene del Vicentino (Italia settentrionale). Studi e Ricerche, Associazione Amici del Museo, Museo Civico "G. Zannato", 2000: 13-16.

Beschin, C., A. De Angeli \& A. CheCChi, 2007 (cf. b). Crostacei dell'Eocene inferiore di Cava "Rossi" di Monte di Malo (Vicenza - Italia settentrionale). Studi e Ricerche, Associazione Amici del Museo, Museo Civico "G. Zannato", 14: 11-24.

Boscardin, M. \& O. Violati Tescari, 1996. Gemme del Vicentino. Pubblicazione Museo Civico "G. Zannato", 1996: 1-114.

De Angeli, A. \& C. Beschin, 2008. Crostacei decapodi dell'Oligocene di Soghe e Valmarana (Monti Berici, Vicenza - Italia settentrionale). Studi e Ricerche, Associazione Amici del Museo Zannato, Museo Civico "G. Zannato", 15: 15-39.

De Angeli, A. \& A. Garassino, 2002. Galatheid, chirostylid and porcellanid decapods (Crustacea, Decapoda, Anomura) from the Eocene and Oligocene of Vicenza (N Italy). Memorie della Società Italiana di Scienze Naturali e del Museo Civico di Storia Naturale di Milano, 30 (3): 1-40.

De Angeli, A. \& A. Lovato, 2009. Sphaeroma gasparellai n. sp. (Isopoda, Flabellifera, Sphaeromatidae), nuova specie di isopode dell'Eocene superiore dei Monti Berici (Italia settentrionale). Lavori — Società Veneziana di Scienze Naturali, 34: 101-104.

Fabiani, R., 1911. Di una nuova specie di Phlyctenodes (Phl. Dalpiazi) dell'Oligocene dei Berici. Bollettino del Museo Civico di Vicenza, 1 (3) (1910): 3-6.

Glaessner, M. F., 1969. Decapoda. In: R. C. Moore (ed.), Treatise on Invertebrate Paleontology, R (Arthropoda 4) (2): R399-R533, R626-R628. (Geological Society of America and University Kansas Press, Lawrence).

MCLAY, C. L. \& S. H. TAN, 2009. Revision of the crab genus Garthambrus Ng, 1996, with the description of two new genera and discussion of the status of Tutankhamen Rathbun, 1925 (Crustacea: Brachyura: Parthenopidae). Zootaxa, 2122: 1-50.

MülleR, P. \& J. S. H. Collins, 1991. Late Eocene coral-associated decapods (Crustacea) from Hungary. Contributions to Tertiary and Quaternary Geology, 28 (2-3): 47-92. 
NG, P. K. L. \& S. H. TAN, 1999. The Hawaiian parthenopid crabs of the genera Garthambrus Ng, 1996, and Dairoides Stebbing, 1920 (Crustacea: Decapoda: Brachyura). Proceedings of the Biological Society of Washington, 112 (1): 120-132.

RagazzI, E., 1998. Ambra: mito e realtà. Studi e Ricerche, Associazione Amici del Museo, Museo Civico "G. Zannato", 1998: 7-16.

TAN, S. H. \& P. K. L. NG, 2007a. Descriptions of new genera from the subfamily Parthenopinae (Crustacea: Decapoda: Brachyura: Parthenopidae). The Raffles Bulletin of Zoology, (Supplement) 16: 95-119.

——\& — , 2007b. Review of the subfamily Daldorfiinae Ng \& Rodríguez, 1986 (Crustacea: Decapoda: Brachyura: Parthenopidae). The Raffles Bulletin of Zoology, (Supplement) 16: 121-167.

Trevisani, E., C. A. Papazzoni, E. Ragazzi \& G. Roghi, 2005. Early Eocene amber from the "Pesciera di Bolca" (Lessini Mountains, Northern Italy). Palaeo, 223: 260-274.

First received 5 May 2009.

Final version accepted 26 June 2009. 